\title{
The Effect of Geometry Box Media on the Ability to Know the Concept of Numbers and Geometric Shapes
}

\author{
Lidia Safitri, Wahyu Sukartiningsih, Sri Setyowati \\ Universitas Negeri Surabaya \\ Surabaya, Indonesia \\ lidya.savitry@gmail.com
}

\begin{abstract}
This research aims to know the influence of geometry box media against the ability to know the concept of numbers and geometric shapes in the group $A$. This research is quantitative approach with the types of experimental quasy research using non-equivalent control group design. Media of geometry box includes one media that can facilitate the learning of cognitive development of the child with regard to geometric shapes and numbers. Therefore, it can be concluded that the influence of the media affects students to know the concept of numbers and geometric shapes in the group $A$.
\end{abstract}

Keywords - geometry box; geometry shape; the concept of numbers

\section{INTRODUCTION}

A child is a person who is undergoing a process of growth and development. Children aged 0-6 years has sensitive (sensitive periods) which is called as the period of the golden ages. According to Montessori (Sujiono, 2009:54-55), this period is a basic foundation in developing all aspects of child's development [1]. Therefore, it needs supporting conditions and stimulation at this time, so the growth and development of the child will be optimal.

One of the aspects of child's development is the aspect of cognitive development. According to Susanto (2011:47), cognitive development is a process of thinking and the ability of an individual to consider an event or events [2]. Cognitive development in Permendikbud No. 137 year 2014 is divided into 3 aspects namely problem solving, logical thinking and symbolic thinking [3].

In the sphere of logical thinking, children are able to recognize the objects according to the pattern, color, shape, the traits/characteristics and functions. Geometry is a part of mathematics in the cognitive classification of logical thinking that needs to be developed in recognizing geometric shapes on existing objects in the surrounding environment. According to Verdine, Lucca, Golinkoff, Hirsh-Pasek \& Newcombe, a form of children's toys has many examples of unusual geometric shapes. There is no clarity as far as where the parents actually had to introduce a form of geometry [4]. Clements and Sarama state that during early childhood education, teacher explains geometric shapes; teachers fail to enrich the knowledge of geometric shapes to the child. Teachers are likely to be asked to identify the form (for example, "what it is?" while holding a triangle) and then just give the correct response, and did not invite children to improve their understanding through discussion that would be the nature of the various forms triangle [5].

According to Levine, Ratliff, Huttenlocher, \& Cannon, knowing the early forms of spatial experience is very important in the development of spatial form and early childhood mathematics. It can be done by playing with a toy that combines a variety of forms (for example, sort geometric shapes), renaming it, and distinguishing the characteristics of geometric shapes. Those are the earliest spatial experience that can be given to the child. Apart from the impact of the experience, there was a recent change in the standard of preschool and kindergarten on spatial ability [6]. Knowledge of geometric forms is an important aspect for school readiness. The ability to know the shape of geometry and spatial learning in mathematics in kindergarten requires children to be able to describe the form of the objects that exist in the surrounding by naming geometric shapes such as a door-shaped rectangular or circular. They can also be trained to mention the name of geometric shapes without regard to the size and shape. Also, they can compare the $2-3$ dimensions in any size with an equation description and difference [7].

As expressed by Clements and Sarama, on the level of prerecognizing, the child may be the best to able to forms the geometric shapes that exist in the world. Help your children to understand what is relevant and irrelevant e.g., orientation, size, color, distinctive shape with activities such as in the following: identify geometric shapes that exist in the classroom, school and community; sort the shapes and describe why a form can be classified in a group shape; replicate and build the shapes using various material [8].

Similar with [9], the introduction of geometric shapes in early childhood is the ability of the child to know, show, mention as well as collect objects in the surrounding environment based on geometric shapes. Triharso also argues that the beginning to introduce children to several geometric shapes can be done by building a thought regarding the geometry shape, starting by identifying geometric shapes; showing the geometric shapes with images/objects; classifying images such as rectangles, triangles, circles, knowing the pattern of the form [10].

In the sphere of symbolic thought, the child is able to get to know the concept of numbers. The number is an important 
part of the concept of counting in math. According to Triharso, numbers is one of the very important mathematical concepts studied in early childhood. It includes the sensitivity to the number of figures [10]. The sensitivity of the number is not just arithmetic matter but it tends to more understand the concept of quantity and suitability. Understanding quantity, like understanding the value or amount of a number such as number one means one thing is good start in case of sensitivity. One example is like in case of understanding the suitability that 2 objects means two things.

Friso-Van Den Bos I, Kroesbergen EH and Van Luit JAH describe that the ability to know the figures on children has increased in the last decade. The ability is about the number counting skills in kindergarten to form the building blocks for the next ability in Math. Number sensitivity is a term that mostly used to characterize the intuitive understanding of number and quantity and something to do. Sensitivity of the number refers to a cognitive framework that allows children to understand. For example, the difference between having two or three mints, but gradually evolved into a much more advanced system of conceptual knowledge that allow child to intuitively understand the relationship of abstract numbers. A variety of capabilities has been considered to be the root of the development of sensitivity number, among them the ability to classify between symbolic and non-symbolic are concerned [11].

In accordance with the opinion of Seigler, it is said that a 2 years child shows the innate knowledge of numbers when brandishing two fingers and loud count "one, two ..." [12]. This kid can respond to some number than they understand the meaning of the "two". The two years child is able to count to ten while in term of memorizing, the children of three to four years is capable of memorizing the count to 20 . So, this does not mean by memorizing, children can do counting and understanding the concept of the early numbers and sometimes the child does not perform right calculations and ignore the one or two numbers because they do not understand the concept of task memory. The child is able to understand that 1 represents the one noun or 5 represent the five oranges.

While Griffin, perform tests of knowledge figures against three children at kindergarten "which is greater: seven or nine?" then one child, Brie, responded quickly, saying "nine". When she was asked how she found the answer, she said, "well, you go, ' seven ' (pause) ' eight ', ' nine ' (putting two fingers while uttering the last two numbers). It means nine is more than seven. So that's bigger. "In this case, the additional proving of Brie was by explanation by using counting to indicate that the nine were two numbers after seven. Brie suggests also that she knows each number in the sequence of computations. This understanding, allows the children to use the numeric calculations only without the need for a real object [13].

According to Triharso, learning math for early childhood should meet a number of principles. One of them is the use of props or media in accordance with the purpose of learning, interesting and it should have many variations [10]. Children should also participate directly in the play in order to gain direct experience and children can understand what is being learnt.

Djamarah and Zain argue that the media are tools that can serve as instruments of the message in order to achieve learning objectives [14]. According to Fadillah, learning media is divided into three things, namely audio, visual and audiovisual media [15]. Visual media is media that rely on vision. Visual media is better used in learning certain situations, compared with audio, especially for early childhood learning. By the use of the senses of vision, the child is able to find out something that is learned. Thus, the presence of the media is expected to create fun learning activities as well as increasing child's interest in getting to know the shape of the geometry, because the concept is a very important to help the child next life.

Media of Geometry Box includes in the learning media of the visual media. Geometry learning media box is made of wood shaped plywood box. This media is named Geometry Box because the shape of the box called "boxes" while "Geometry" has the meaning of geometric forms. Geometric shapes are existed in the media, and those media are expected to facilitate the child's cognitive ability. Media Geometry Box sized $\mathrm{p} \times 1 \times \mathrm{t}$ the size of A3 paper, with an estimated size of approximately $44.5 \mathrm{~cm} \times 32 \mathrm{~cm} \times 32 \mathrm{~cm}$.

In media Geometry Box, there are a geometric-shaped pieces including a triangle, square, circle and rectangle that are used to introduce other forms of geometry in children. The pieces illustrate objects surrounding that looks like geometric shapes including cabinets, clock wall, and desk. They are all used to classify geometric shapes that correspond to the objects. There are also the numbers of 1-10 to introduce the concept of numbers. Media Geometry Box is equipped with measuring sticks $\pm 34 \mathrm{~cm}$ and hole-shaped Geometry for geometry puzzle. Media Geometry Box is colored in order to interest children to play and learn. It is simple yet can teach such activities regarding the concept of numbers and geometric shapes with fun.

Previous research which is relevant to the research was done by Sulistina (2014) on the influence of media use of Cuisenaire beam towards mastery the concept of numbers and activity of the child. It indicates that the results of the use of the influential media can significantly influence the mastery of the concept of numbers and activity of children. This is evident from the MANOVA test result that has a value of $F$ count the significance of 13.485 is greater than $4.01 \mathrm{~F}$ table.

While the study by Rahayu (2016) about the development of the media magic box expression to enhance the ability of logical thinking and the expressive language in early childhood showed that the use of the media magic box expression can improve the ability of logical thinking and the expressive language in early childhood. This is evident from the results of research that has an F count of $(-5.618)$ which is greater than $\mathrm{F}$ table of $(-2.045)$. It shows that there is a 
difference in average pretest and posttest on learning to use the media of magic expression box.

The research was also done by Full (2016) about the development of the media box to teach the numbers and operations for the students classes 1 SDN Gadang. It aims to facilitate the dissemination of numbers and operations by developing a media box. Media box can be a choice of media by teachers to address the availability of media in math learning. It enables and in accordance with the child's development. The results showed that the media is arguably valid, practical, interesting and effective so that it can be used in the process of learning math.

According to Sudjana \& Rivai, learning media has value and benefits including: (1) Teaching would be more attractive and can foster students' motivation, (2) teaching materials are more clearly that it can be better understood by the students, and allows students to master the objective of the teaching, (3) method of teaching will be more varied, not merely using verbal communication through the utterance of words by teachers. It resulted to drive away students' boredom especially when teachers taught lessons for several hours, (4) Students doing more learning activities, they do not only listen to the teacher's explanation, but they also do other activities such as observing, performing, demonstrating and others [16].

According to Arsyad, instructional media selection criteria should be concerned to some consideration below: medium used should fit with the results aimed, media content must be appropriate and supports the content of the material, practical and flexible; media is used in accordance with the target. [17]

Based on the above description, there must be such study to introduce the four geometric shapes and develop sensitivity to the number for the child in the kindergarten of group A by using media geometry Box as the consummation of the previous studies. The researchers are eager to find out the extent of the influence of media geometry Box. It also gives these children the opportunity to develop the ability to know the geometric shapes and the concept of numbers 1-10. Therefore, the need for research on the influence of media geometry Box against the ability to know the four geometric shapes and numbers 1-10 in Group A Sub district Tambaksari Surabaya in kindergarten was done.

\section{METHOD}

This research uses a quantitative approach with experimental research. This research uses a type of experiments research with quasi experimental design type of nonequivalent control group design. The sample in this research was A group of TK Gembira on A class where A1 consisting of 25 children and A2 consisting of 25, while TK Budi Luhur class A1 consisting of 30 children and class A2 consisting of 25 . From the explanation above, the total sample used in this study were 105 children who were divided into two classes, namely experimental class and control classroom. Classroom experiments in this study consisted of two classes with a total sample as many as 50 children, while the control classroom consists of two classes with a total sample of 55 children.

Data collection techniques of this research were observations accompanied with the observation sheet and documentation in the form of photos and videos. The scale used in this research was the rating scale of 1-4 scale, in which are written with an asterisk. The use of the asterisk is the symbol to indicate the level of achievement of the child's development as a result of the teacher's observations.

This research used data analysis by employing Anova and Manova on significance level $=0.05$ using SPSS program 22 for windows. The first hypothesis test is media geometry box effect on the ability to know the four geometric shapes and the second hypothesis, namely media geometry Box effect on the ability to know the concept of numbers 1-10, and the third hypothesis, is media geometry Box effect on the ability to know the four geometric shapes and numbers 1-10.

\section{RESUlTS AND DisCUSION}

TABLE I. PARTS OF MEDIA IN GEOMETRY BOX

\begin{tabular}{|l|l|l|}
\hline No. & $\begin{array}{c}\text { The Name of The Part } \\
\text { Geometry Box Media }\end{array}$ & Media Geometry Box Specifications \\
\hline 1. & Box & $\begin{array}{l}\text { - Plywood sized pxlxt- }=44.5 \mathrm{~cm} \times 32 \\
\text { cm x } 32 \mathrm{~cm} \\
\text { Divided the two parts of the top and } \\
\text { bottom. The top is given delimiter } \\
\text { into } 4 \text { sections. The bottom is not } \\
\text { given delimiter. Part of that section is } \\
\text { used for storage. }\end{array}$ \\
\hline 2. & Geometric puzzle Board & $\begin{array}{l}\text { - Size pxlxt }=42 \mathrm{~cm} 30 \mathrm{~cm} \times 30 \mathrm{~cm} \\
\text { consists of a puzzle consisting of } 4 \\
\text { geometry things, namely a square, } \\
\text { triangle, circle and rectangle }\end{array}$ \\
\hline 3. & Geometric pictorial piece & $\begin{array}{l}\text { Square: } 165 \text { form (size } 3 \mathrm{~cm} \times 2.5 \mathrm{~cm}) \\
\text { Triangle: } 165 \text { form (size } 3 \mathrm{~cm} \times 2.5 \mathrm{~cm}) \\
\text { Circle: } 165 \text { shape (diameter } 3 \mathrm{~cm}) \\
\text { Rectangle: } 165 \text { form (size cm x } 2.5 \mathrm{~cm})\end{array}$ \\
\hline 4. & Wooden sticks & $\begin{array}{l}\text { Wooden sticks measuring } 34 \mathrm{~cm} \text { long } \\
\text { with a total of } 10 \text { pieces. }\end{array}$ \\
\hline
\end{tabular}

Validation of the media learning Geometry Boxes was organized into aspects based on the measured. Furthermore, media validation instrument Geometry Box was brought to the expert to be validated. At the time of validation of media Geometry Box it was attached RPPM, RPPH, research instrument and how to play using media Geometry Box. The next stage was the validation research instrument. Media Geometry tool box is an educational game designed specifically to stimulate cognitive development of the child, namely the ability to know the shape of the geometry and the concept of number. Parts of media geometry box are shown by Table I.

\section{CONCLUSION}

Based on the results of research and discussion, the media of geometry box can facilitate the development of children' cognitive skill associated with logical thinking. It was proven that they know the four geometric and symbolic thinking i.e. know the concept of numbers one to ten. Therefore, it can be 
inferred that, (1) there is such influence of the geometry box media against the ability to know the four geometric shapes (triangle, square, circle and rectangle) in Group A; (2) there is such influence of geometry box media against the ability to know the concept of numbers one to ten in Group A; (3) there is such influence of geometry box media against the ability to know the concept of numbers and geometric shapes in the group A.

\section{REFERENCES}

[1] Sujiono, Yuliani Nurani. 2009. Konsep Dasar Pendidikan Anak Usia Dini. Jakarta: PT Indeks.

[2] Susanto, Ahmad. 2011. Perkembangan Anak Usia Dini. Jakarta: Kencana Prenada Group.

[3] Peraturan pemerintah No. 137 tahun 2014. Standar Nasional Pendidikan Anak Usia Dini. Departemen Pendidikan Nasional.

[4] Verdine, Lucca, Golinkoff, Hirsh-Pasek \& Newcombe, 2015. The Shape of Things: The Origin of Young Children's Knowledge of the Names and Properties of Geometric Forms. J Cogn Dev. 2016 Jan 1; 17(1): 142-161. Published online 2015 Mar 31. doi: 10.1080/15248372.2015.1016610 PMCID: PMC4808058

[5] Sarama J, Clements DH. Building Blocks for early childhood mathematics. Early Childhood Research Quarterly. 2004;19(1):181-189. doi: 10.1016/j.ecresq.2004.01.014

[6] Levine SC, Ratliff KR, Huttenlocher J, \& Cannon J. 2012. Early Puzzle Play: A Predictor of Preschoolers' Spatial Transformation Skill. Developmental Psychology. Vol. 48, No. 2, 530-542. doi: 10. 1037/a0025913

[7] Common Core State Standards Initiative. Common core state standards for mathematics. $2010 \quad$ Retrieved from http://www.corestandards.org/Math.

[8] Clements Douglas H and Sarama Julie. 2000. Young Children's Ideas about Geometric Shapes. Teaching Children Mathematics. Pages 483488.

[9] Lestari K. W. 2011. Konsep Matematika. Jakarta: Departemen Pendidikan dan Kebudayaan. Derektorat Jendral Pendidikan Anak Usia Dini Nonformal dan Informal, Direktorat Pembinaan Pendidikan Anak Usia Dini.

[10] Triharso, Agung. 2013. Permainan Kreatif \& Edukatif Untuk Anak Usia Dini. Yogjakarta: ANDI

[11] Friso-van den Bos I, Kroesbergen EH and Van Luit JEH. 2018. Counting and Number Line Trainings in Kindergarten: Effects on Arithmetic Performance and Number Sense. Front. Psychol. 9:975. doi: 10.3389/fpsyg.2018.00975

[12] Beaty, Janice. J. 2013. Observasi Perkembangan Anak Usia Dini. Jakarta: Kencana.

[13] Griffin, S. 2004. Building number sense with Number Worlds: a mathematics program for young children. Early Childhood Research Quarterly, Pages 173-180.

[14] Djamarah, dkk. 2010. Strategi Belajar Mengajar. Jakarta: Rineka Cipta.

[15] Fadillah. Muhammad. 2014. Desain Pembelajaran PAUD. Jogjakarta: Ar-Ruzz Media.

[16] Sudjana, dkk. 2010. Media Pembelajaran. Bandung: Sinar Biru Algensindo.

[17] Arsyad, Azhar. 2008. Media Pembelajaran. Jakarta: PT Raja Grafindo Persada. 